\title{
The carceral existence of social work academics: a Foucauldian analysis of social work education in English universities
}

\author{
DIANE SIMPSON \& SARAH AMSLER \\ University, Country
}

\begin{abstract}
Applying Foucault's concepts of disciplinary power and technologies of the self to the experiences of social work academics in English universities, this articles reveals their carceral existences, arguing that social work academics and their students exist within a "carceral network" which controls and normalises behaviour by simultaneously trapping them within and excluding them from succeeding in academic practices. While social work academics become "docile bodies" as they are shaped and trained by competing norms of neoliberal higher education and professional social practice, their position as insiders and outsiders to both can also enable them to resist certain disciplinary expectations. The findings of the qualitative study discussed in this article support Foucault's analysis of powerful institutions but problematise binary positions of docility or resistance to disciplinary power within them. Lived experiences of 'becoming academic' in English social work education reveal how normalising judgements and hierarchical observation intersect with neoliberal forms of responsibilisation to create a carcerality rooted in "incompetence"; how "technologies of relationships" are used to mediate individual forms of responsibilisation, and how having to negotiate multiple disciplinary regimes can create opportunities for resistance to each.
\end{abstract}

Keywords: social work education; disciplinary power; technologies of the self; carcerality of incompetence; compensatory gaze; technologies of relationships.

\section{ACKNOWLEDGEMENTS}

An earlier version of this paper was delivered at the Society for Research into Higher Education Conference in 2015 and is based on the doctoral thesis of one of the authors. ${ }^{1}$

\footnotetext{
${ }^{1}$ Diane Simpson "Being and Becoming a Social Work Academic: Negotiating Transitions and Identities" (EdD diss., University of Lincoln, 2016).
} 


\section{RESEARCH CONTEXT}

This paper reports on the findings of a doctoral study about social workers who become social work academics in English universities. The study combined Foucault's work on disciplinary power and technologies of the self but also developed additional concepts, "technologies of relationships," "carcerality of incompetence" and "compensatory gaze," in response to the carceral setting of English social work education, largely typified by a perceived lack of overt hierarchical observation. Foucault ${ }^{2}$ described hierarchical observation as central to disciplinary control through "...a mechanism that coerces by means of observation" and "...the means of coercion make those on whom they are applied clearly visible." And yet, English social work academics are, initially at least, unfamiliar with this anonymous institutional gaze, experienced as a lack of gaze. Technologies of relationships refers to the facilitative relationships they established with peers to create a 'compensatory gaze' that supported their professional survival within the academy where hierarchical observation, while present in responsibilised form, was neither perceived nor fully understood. By learning to navigate the considerable and often competing demands of social work and academic life, social work academics became ensnared in what we call a "carcerality of incompetence", disciplining themselves and each other to internalise normalising discourses that constrained their professional identities and autonomy. However, being located at the intersection of these competing normalising discourses (of the university and social work) also gave these social work academics insight into the contingency and non-necessity of each, and opened spaces of possibility for challenging the hegemonic power of neoliberal governance in the university.

\section{THE BIRTH OF THE ‘SOCIAL WORK ACADEMIC’ IN ENGLAND}

Whilst there is a long-standing history of social work education within universities in England, ${ }^{3}$ only since 2003 has it been mandatory to qualify at degree level ${ }^{4}$ (part of a wider trend towards academic professionalisation within the caring professions; ${ }^{5}$ ) and the 'neoliberal' university - a "market-driven system, which employs modes of governance based on a corporate model". ${ }^{6}$ However, the provision, configuration and content of social work qualifying degrees remains a hotly debated and contentious area as the shift towards educating graduate-level social workers has been driven by dual priorities to

\footnotetext{
${ }^{2}$ Michel Foucault, Discipline and Punish: The Birth of the Prison [1975] (1991), 174.

${ }^{3}$ Jill Manthorpe, "Settlement and Social Work Education: Absorption and Accommodation," Social Work Education 21:4 (2002), 411.

${ }^{4}$ Evaluation of the Social Work Degree Qualification in England Team, Evaluation of the New Social Work Degree Qualification in England: Volume 1: Findings (2008), 1.

${ }^{5}$ Jo Moriarty et al., "A Degree of Success? Messages from the New Social Work Degree in England for Nurse Education," Nurse Education Today 30:5 (2010), 443; Nursing and Midwifery Council, Nurse Education: Now and In the Future (2010).

${ }^{6}$ Eimear Enright, Laura Alfrey, and Steven B. Rynne, "Being and becoming an academic in the neoliberal university: a necessary conversation," Sport, Education and Society 22:1 (2017), 1-4.
} 
prepare social workers for practice (predominantly articulated as, and driven by, safeguarding practice within local authorities) and improve the cognitive and practical skills of university graduates. ${ }^{7}$ As becoming a 'graduate profession' requires social work courses to be delivered by academics who are/or have been social work practitioners, and includes co-delivery with service users and practitioners, these tensions are embodied in the identities and experiences of those who are committed to practising social work within the context of a competitive, commercialised university system that increasingly demands individuals "accept responsibility for the self but...shed any responsibility for others except to participate in acts of surveillance and control." 8

While there is now a substantial evidence base about practitioners who become academics in their fields, ${ }^{9}$ the experiences of social work academics are largely absent from the literature. Much of that which does exist focuses on biographical accounts of challenges faced by social work academics in relation to research productivity and engagement, ${ }^{10}$ and stress, ${ }^{11}$ with a more recent addition of a doctoral study examining academic identities and academic careers. ${ }^{12}$

Michel Foucault's insights into how the internalisation of disciplinary norms and expectations ${ }^{13}$ shape the complex relationship between structural power and individual action offers a 'toolbox'14 for understanding the production of "docile bodies"15 within powerful institutions such as the university. This enables us to discern how disciplinary power is embedded within institutional practices through various mechanisms, including

\footnotetext{
${ }^{7}$ Evaluation of the Social Work Degree Qualification in England Team, Evaluation of the New Social Work Degree Qualification in England, 1.

8 Bronwyn Davies, "Subjectification: the relevance of Butler's analysis for education," British Journal of Sociology of Education 27:4 (2006), 425-438.

${ }_{9}^{9}$ Bruce Macfarlane, "Business and Management Studies in Higher Education: The Challenge of Academic Legitimacy," International Journal of Educational Management 9:5 (1995), 4; Annie Pettifer and Lynn Clouder, "Clinical Supervision: A Means of Promoting Reciprocity Between Practitioners and Academics," Learning in Health and Social Care 7:3 (2008), 168-177; Lesley Gourlay, Transitions into the Academic World: Identities and Academic/Literary Practices (2010); Alison Shreeve, "Being in Two Camps: Conflicting Experiences for Practice-Based Academics," Studies in Continuing Education 33:1 (2011), 81; Sue Field, "The Trials of Transition, and the Impact Upon the Pedagogy of New Teacher Educators," Professional Development in Education 38:5 (2012), 811-826; Sally Findlow, "Higher Education Change and Professional-Academic Identity in Newly 'Academic' Disciplines: The Case of Nurse Education," Higher Education 63:1 (2012), 117-133.

${ }^{10}$ Mike Fisher and Peter Marsh, "Social Work Research and the 2001 Research Assessment Exercise: An Initial Overview," Social Work Education 22:1 (2003), 75; Joan Orme, “Why Does Social Work Need Doctors?," Social Work Education 22:6 (2003), 541-554; Economic and Social Research Council, An Audit of Baseline Resources for Social Work Research: Finances, Staff, Teaching (2008), 81-82; Jackie Powell and Joan Orme, "Increasing the Confidence and Competence of Social Work Researchers: What Works?," British Journal of Social Work 41:8 (2011), 1568.

11 Stewart Collins and Beth Parry-Jones, "Stress: The Perceptions of Social Work Lecturers in Britain," British Journal of Social Work 30:6 (2000), 769-794.

12 Paula Sobiechowska, "The Professional-Academic: Negotiating the Relationships Between Professional, Practitioner and Academic Identities Among Social Worker and Nurse Educators" (Phd diss., UCL Institute of Education, 2016), 5.

${ }^{13}$ Michel Foucault, Discipline and Punish, 170-194.

${ }^{14}$ Gary Gutting, Foucault: A Very Short Introduction (2005), Chap.1, Kindle.

${ }^{15}$ Discipline and Punish, 138.
} 
the use of space, regimes to manage time and behaviour, hierarchical observation, normalising judgements and examination. ${ }^{16}$

The theory of disciplinary power has been used as a lens to analyse a range of contexts and issues in both social work and university life, thus making it particularly appropriate for this study. ${ }^{17}$ This includes research into how surveillance regulates the behaviours of service users and social work practitioners in the UK, ${ }^{18}$ and how surveillance, normalising judgements and power in USA welfare offices control both benefit claimants and practitioners. ${ }^{19}$ In Higher Education Studies, theories of disciplinary power have been used to analyse themes ${ }^{20}$ including the Research Excellence Framework (REF), ${ }^{21}$ the practice of funded research, ${ }^{22}$ the exclusion of Black academics from publishing ${ }^{23}$ and the gendered nature of academic appraisal. ${ }^{24}$. Yet while the broad notion of disciplinary power is widely used in these fields, neither its intersecting dimensions ${ }^{25}$ nor the specific

\footnotetext{
${ }_{16}$ Discipline and Punish, 135-228; Clare O'Farrell, Michel Foucault (2005), 103-105.

${ }^{17}$ This includes dietetics in world class swimming - Jennifer Ann McMahon and Dawn Penney, "(Self-) Surveillance and (Self-) Regulation: Living by Fat Numbers Within and Beyond a Sporting Culture," Qualitative Research in Sport, Exercise and Health 5: 2 (2013), 157-178; health care practices - Liz Forbat et al., "The Use Of Technology in Cancer Care: Applying Foucault's Ideas to Explore the Changing Dynamic of Power in Health Care," Journal of Advanced Nursing 65:2 (2009), 306-315; health visiting - Sue Peckover, "Supporting and Policing Mothers: An Analysis of the Disciplinary Practices of Health Visiting," Journal of Advanced Nursing 38:4 (2012), 369-377; and prisons - Michael Dutton, "Disciplinary Projects and Carceral Spread: Foucauldian Theory and Chinese Practice," Economy and Society 21:3 (1992), 276-294.

${ }_{18}$ Tony Gilbert and Jason L. Powell, "Power and Social Work in the United Kingdom: A Foucauldian Excursion," Journal of Social Work 10:1 (2010), 3-22.

${ }^{19}$ Ken Moffatt, "Surveillance and Government of the Welfare Recipient," in Reading Foucault for Social Work, ed. Adrienne S. Chambon, Allan Irving and Laura Epstein (1999), 219-245.

${ }^{20}$ Lee-Ann Broadhead and Sean Howard, "The Art of Punishing": The Research Assessment Exercise and the Ritualisation of Power in Higher Education," Education Policy Analysis Archives 6:8 (1998), 1-14; Stephen Fox, "The Panopticon: From Bentham's Obsession to the Revolution in Management Learning," Human Relations 42:8 (1989), 717-739; Adrian Peter Kelly, "Re-Stor(y)ing Power, Intimacy and Desire in Academic Work: Relational Academic Development and Learning Development in Practice" (EdD. Diss., University of Technology, Sydney, 2012), 152.

${ }^{21}$ Broadhead and Howard, "The Art of Punishing," 1-14; Geoffrey Harding and Kevin M. G. Taylor, "Academic Assessment in the Carceral Society," Pharmacy Education 1:2 (2001), 77-82.

${ }^{22}$ Chris Allen, "On the Social Relations of Contract Research Production: Power, Positionality and Epistemology in Housing and Urban Research," Housing Studies 20:6 (2005), 989.

${ }^{23}$ Katherine Grace Hendrix," Dialoguing with the "Communication Chorus": Mapping the Contours of the Morass," Southern Communication Journal 75:2 (2010), 127 -136.

${ }^{24}$ Fiona Wilson and Sandra Nutley, "A Critical Look at Staff Appraisal: The Case of Women in Scottish Universities," Gender, Work and Organization 10:3 (2003), 310 -319.

${ }^{25}$ An exception is Stephen Demeo, "Gazing at the Hand: A Foucauldian View of the Teaching of Manipulative Skills to Introductory Chemistry Students in the United States and the Potential for Transforming Laboratory Instruction," Curriculum Inquiry 35:3 (2005), 305-315.
} 
concept of 'carcerality'26 have been systematically discussed. When carcerality ${ }^{27}$ is addressed, it tends to be contextualised among the main elements of disciplinary power, in particular observation, examination, and normalising judgement. Social work academics in England, however, are situated within "neoliberalised" institutions in which governance is characterised less by forms of hierarchical observation and more by a "technology of indirect management" or responsibilisation. ${ }^{28}$ Responsibilisation replaces both "hierarchies of direct governance and horizontal collaborative decision-making with bench-marks, standards, and targets" that are "implemented by administrative authorities" but "realised by persons who are monitored and audited for performance and results". ${ }^{29}$ Within this system, an individual is conceptualised as a "subjective being who aspires to autonomy, interprets its reality in terms of individual responsibility and who shapes its life through acts of choice" 30 within "a coercive non-democratically developed matrix of standards, strategies, and objectives that determine what is 'recognisable' (expected) academic activity" 31.

This study revealed that for practitioner academics who are new to the academy, this type of 'freedom' or 'autonomy' can be experienced as a neoliberal form of "carcerality" which disciplines the meanings of both social work practice and education, as well as social work academics' efforts to be and become academic. The study thus identifies a form of discipline that is perceived by social work academics as a "lack of gaze" which compels the self-construction not only of earnest "technologies of the self" but also what we term a "compensatory gaze" that is mediated through "technologies of relationships." This alternative form of collective self-discipline, which Foucault did not emphasise in his work, allows practitioners to conform to the expectations of hierarchical observation within the neoliberal university while being located within a "carcerality of incompetence" that places them at both a higher risk of professional punishment than colleagues who were already normalised within the academic system and of feeling

\footnotetext{
${ }^{26}$ For example: Fox, "The Panopticon" 717-739; “The Art of Punishing," 1-14; Peckover, "Supporting and Policing," 372-375; Wilson and Nutley, "A Critical Look," 310-319; Allen "On the Social Relations of Contract Research Production," 989-1007; Caroline Bradbury-Jones, Sally Sambrook and Fiona Irvine, "Power and Empowerment in Nursing: A Fourth Theoretical Perspective," Journal of Advanced Nursing 62:2 (2008), 261263; Gilbert and Powell, "Power and Social Work," 7; Michael I. Cohen, "In the Back of Our Minds Always: Reflexivity as Resistance for the Performing Principal," International Journal of Leadership in Education: Theory and Practice 17:1 (2014), 16-17; John Flint, "The Inspection House and Neglected Dynamics of Governance: The Case of Domestic Visits in Family Intervention Projects," Housing Studies 27:6 (2012), 831-834; Katherine McLean, "Reducing Risk, Producing Order: The Surprisingly Disciplinary World of Need Exchange," Contemporary Drug Problems 40:3 (2013), 431.

27 Dutton, "Disciplinary Projects and Carceral Spread", 276-294; Harding and Taylor "Academic Assessment," 77-82.

${ }^{28}$ Mark Amsler and Cris Shore, "Responsibilisation and Leadership in the Neoliberal University: A New Zealand Perspective," Discourse: Studies in the Cultural Politics of Education 38:1 (2017), 124 (emphasis added). ${ }^{29}$ Amsler and Shore, "Responsibilisation," 126.

${ }^{30}$ Andrew Morrison, "Hegemony through Responsibilisation: Getting Working-Class Students into Higher Education in the United Kingdom," Power and Education 6:2 (2014), 120.

31 "Responsibilisation," 135.
} 
"inauthentic"32 or contravening their own professional ethics as social workers. Compensatory gaze is distinct from traditional anonymised Foucauldian gaze in a number of ways. Crucially, compensatory gaze is horizontal/flat and mutual, rather than hierarchical, and its purpose is to facilitate and support rather than to "...coerce by means of observation". ${ }^{33}$ Further, for Foucault, there is "constant surveillance" 34 or an internalised anticipation of being watched, which influences behaviour and enforces compliance of the subject in a "laboratory of power" ${ }^{35}$ Conversely, compensatory gaze was created in response to the experience of complete lack of gaze with no particular aim to control the subject. Whilst anyone may inhabit the Panopticon's control tower, ${ }^{36}$ typically this position ensures power and control are exerted upon subjects as they are observed, evaluated and details recorded, "the Panopticon is a privileged place for experiments on men (sic) and for analysing with complete certainty the transformations that may be obtained from them". ${ }^{37}$ This is not the case for compensatory gaze, as this does not seek to study, record or correct the behaviour of individuals (apart from helping them understand the context of higher education). Moreover, in hierarchical observation, "He is seen, but he does not see; he is the object of information, never a subject in communication," 38 whereas in the compensatory gaze and its mutual relationships, social work academics are subjects in a mutual interaction and communication; additionally, interactions tend to be informal and not documented. There is convergence between compensatory gaze and hierarchical observation to some extent insofar as it might be argued that by creating a compensatory gaze, social work academics unwittingly internalise power of the anonymised gaze. Compensatory gaze is therefore a nonhierarchical horizontal gaze created between social work academics, particularly new staff members, to mediate against experiences of a lack of gaze and oversight within university practices. Compensatory gaze provides a supportive, collegial and noncoercive infrastructure, operationalised within technologies of relationships with peers (and occasionally those with more experience), through which social work academics learn the craft of academic practice. Such gaze compensated for the apparent lack of hierarchical observation and supervision of practice and was deemed as important for developing skills and competence in their new professional role as an academic. The mutual, horizontal, technologies of relationships facilitated a network of relationships

\footnotetext{
32 Feeling inauthentic is extensively documented in relation to various professional disciplines; for example: John Blenkinsopp and Brenda Stalker, "Identity Work in the Transition from Manager to Management Academic," Management Decision 42:3/4 (2004), 424; Sue Clegg, "Academic Identities Under Threat?," British Educational Research Journal 34:3 (2008), 338; Vivienne Griffiths, Simon Thompson and Liz Hryniewicz, "Developing a Research Profile: Mentoring and Support for Teacher Educators," Professional Development in Education 36:1-2 (2010), 251; Lesley Gourlay, "New Lecturers and the Myth of 'Communities of Practice'," Studies in Continuing Education 33:1 (2011), 73; Sally Findlow, "Higher Education Change," 128.

33 Discipline and Punish, 170.

34 Ibid, 199.

35 Ibid, 204.

36 Ibid, 202.

37 Ibid, 204.

38 Ibid, 200.
} 
where everyone could be compensated for the perceived lack of gaze and assistance in becoming academics, and where every person could contribute to the provision of compensation (although this was not necessarily well informed, carrying the risk of carcerality of incompetence).

At the same time, as they are located both within and external to the university and the social work profession, social work academics are subject to and negotiate competing normalising judgements in social work practice and higher education. Participants in this study tended to respond more favourably to those that emphasised the values of social work practice and safeguarding the interests of service users and carers, and either disregarded or only partially accepted, neoliberal norms of efficiency and economic value of this work, which were regarded as contrary to the interests of service users and the social work profession. Far from being only what Foucault referred to as docile bodies, therefore, social work academics working at this intersection thus have the potential to be both "resistant" or "seditious academics" who disrupt processes of normalisation, as well as enforcers of normalised professionalism in their own right. This paper therefore rethinks how carcerality operates and is negotiated within the neoliberal English university, drawing on the lived experiences of social work practitioners who join it from professional practice.

\section{A CASE STUDY OF SOCIAL WORK ACADEMICS IN ENGLISH UNIVERSITIES: METHODOLOGY}

This paper draws on a qualitative, interview-based doctoral study of 21 social work academics in English universities. ${ }^{39}$ The research explored their experiences of transitioning from practitioner to academic, focusing on engagement with academic practices and the development of academic identities within the macro context of the English neoliberal university and the micro context of social interactions with others, including the role of agency.

A purposive sampling strategy identified "key informants" 40 with specific inclusion criteria; i.e. employment as social work educators in academic posts and also registered social workers with the regulatory body, the Health and Care Professions Council (HCPC). In December 2019, Social Work England took over from HCPC as the regulatory body for social work in England. Ethical approval and participants' full informed consent were obtained. Twenty-one social work academics were interviewed, derived from 5 different universities (3 post 1992 universities and 2 pre 1992 universities), based in 3 different geographical regions of England. Twelve participants were from one university and there were single participants from 2 of the universities; however, themes that arose in the data were applicable to all contexts. Participants held a variety of posts ranging from lecturer to head of social work programmes, with varying number of years of academic employment. Sixteen of the participants were white British; the other 5

\footnotetext{
39 Simpson, "Being and Becoming", 2016.

${ }^{40}$ Alan Bryman, Social Research Methods (2008), 460.
} 
participants self-described their ethnic identity as Caucasian, European, dual heritage, Irish and British. There were 15 women and 6 men in the sample. Both gender and ethnic origin reflect the wider racial and gender imbalances within the social work profession in England; ${ }^{41}$ the absence of black social work academics is particularly concerning given the diverse ethnic composition of the wider qualified practitioner workforce in social work. ${ }^{42}$ There were no academics under the age of 35. Nine had been academics for 5-10 years, and only 5 participants had been academics for 4 years or less. Interviews were audio recorded, transcribed verbatim and subject to respondent validation ${ }^{43}$ with 2 participants making minor amendments to transcripts which were visible using track changes to retain the integrity of the data and a clear audit trail in order to enhance project "trustworthiness" 44 and academic rigour.

A Foucauldian-inspired discourse analysis produced detailed insights ${ }^{45}$ into the experiences of social work academics and provided a nuanced understanding of academic identities, academic labour and transition experiences. The data was initially analysed using iterative coding and re-coding cycles"6 and was "structural" 47 to the research questions, with subsequent coding undertaken in order to reveal the function of discourse in participants' lived experiences. An important part of this second-cycle theoretical coding was the use of In Vivo coding ${ }^{48}$ to use participants' own words to capture their lived experiences. Coding was done using Nvivo 8 software, which generated an audit trail that supported clear decision making within the project and analytical rigour. ${ }^{49}$

One of the authors was a social work academic, a staff member in one of the universities, and a HCPC registered social worker, and was therefore both "insider" in all university contexts whilst an outsider in employment status. This multifaceted positioning necessitated a careful consideration of positionality. While their insider researcher status provided access to some participants and a lived understanding of the context of social work education in the neoliberal university, it also introduced risks such as distortion..$^{50}$ These were minimised by prioritising critical self-awareness in the research in which the researcher took care not to influence participants' perspectives, used careful paraphrase and promoted a narrative approach, coupled with active listening, so participants could provide unfettered accounts of their experiences as far as possible.

\footnotetext{
${ }^{41}$ Health and Care Professions Council, Registered Social Workers July 2014 (2014).

${ }^{42}$ General Social Care Council, Regulating Social Workers (2001-12), Learning Report (2012).

43 Alan Bryman, Social Research Methods, 377.

${ }^{44}$ Yvonna S. Lincoln and Egon G. Guba, Naturalistic Inquiry (1985), 289-331.

45 Social Research Methods, 500; Marlene Morrison, “What Do We Mean by Educational Research?” in Research Methods in Educational Leadership and Management, ed. Ann R.J. Briggs and Marianne Coleman (2007), 27.

${ }^{46}$ Johnny Saldaña, The Coding Manual for Qualitative Researchers (2013), 58.

47 Saldaña, The Coding Manual, 84.

48 The Coding Manual, 91.

${ }^{49}$ Allen Rubin, "Standards for Rigor in Qualitative Inquiry," Research on Social Work Practice 10:2 (2000), 175;

Pamela Baxter and Susan Jack, “Qualitative Case Study Methodology: Study Design and Implementation for Novice Researchers," The Qualitative Report 13:4 (2008), 555-556.

${ }^{50}$ Justine Mercer, "The Challenges of Insider Research in Educational Institutions: Wielding a Double-Edged Sword and Resolving Delicate Dilemmas," Oxford Review of Education 33:1 (2007), 7-8.
} 


\section{ELEMENTS OF “CARCERAL DISCIPLINE” IN SOCIAL WORK EDUCATION}

These experiences, as presented in the following section, illustrate that social work academics in these universities operated within a complex system of discipline which demanded conformity to academic practices whose rules were not made explicit and that contradicted other norms of social work practice. In this system, social work academics constructed both individual and collective technologies in order to decode the tacit rules of neoliberal observation, judgment and examination and strategically prioritise competing norms of higher education and social work practice (see also Figure 1). The following section explores how this particular form of discipline was experienced by participants as a "lack of gaze" or imposed incompetence; how this was exercised through normalising judgements, the control of activity and the distribution of space; how they negotiated competing sets of normalising judgements in this setting; and how they positioned themselves as both examined and examining subjects within the system.

\section{Becoming academic alone: from hierarchical observation to a responsibilisation}

Surveillance through hierarchical observation is fundamental to the exercise of a certain kind of disciplinary power through which individuals submit to the 'gaze' of an internalized judge or examiner ${ }^{51}$. Gaze (in this case, e.g., oversight of work and checking for compliance with procedural requirements) is typical within social work practice in the $\mathrm{UK}^{52}$. Becoming familiar with the requirements of university systems that are organised around indirect governance ${ }^{53}$ is therefore a challenge for practitioner academics ${ }^{54}$. The social work academics who participated in this study reported an absence of a discernible "gaze" during their transition into academic practice. This raised questions about the impact of a perceived "lack of gaze" on disciplinary power in neoliberal universities, and suggested the need for a more nuanced conceptual understanding of this issue. As one remarked,

"it was the systems around things but also the culture of the organisation was so different to where I'd worked before...that it was...it was a bit, it was just a bit of a shock. It appeared to be very easy-oasy compared to a local authority where people were clocking in and clocking out...nobody was very interested in whether you were there or not...much more laissez faire approach and yet at the same time people were counting the pages that you photocopied." (P10 - University 2)

According to another comparing academic to social work practice,

...here, you're kind of left (laughs) and if you can't work out how to do it, and you don't do it, probably no-one would even notice and there's things, you know, there's no

\footnotetext{
${ }^{51}$ Discipline and Punish, 170-177.

52 "Power and Social Work," 10.

53 Thomas Lemke, "Foucault, Governmentality, and Critique," Rethinking Marxism 14:3 (2002), 59.

${ }_{54}$ Peter Boyd, Lily Baker, Kim Harris, Chris Kynch and Emma McVittie, Working with Multiple Identities: Supporting New Teacher Education Tutors in Higher Education (2006), 5; Griffiths, Thompson, and Hryniewicz, "Developing a Research Profile," 250; Gourlay, "New Lecturers," 69; Field, "The Trials of Transition," 7.
} 
written processes, there's no policies, there's no supervision, there's no monitoring of what you're doing, no-one really knows what you do. (P7 - University 5)

Participant 10 further added:

I would sit in module meetings and think, you know, there were lots of, you know, shorthand used that I didn't understand it, so that bit was quite difficult and I got sick of hearing myself saying so what does that mean, how does that link together, if I do X, what, you know, what's the knock on effect of that. So I didn't have the big picture to really understand everything that was happening. (P10, University 2)

They typically had to make their own arrangements for access to office, equipment and induction. The absence of a supportive gaze during the transition into academic practice is symptomatic of the disorganised (and often absent) induction processes experienced by participants and also indicates the potential importance of clearly defined mentoring.

When [I saw] the programme leader on the Friday, I'd sat for 4 days on my own, I can't tell you how long them days felt, just like, well I didn't know what to do and I thought somebody's bound to know. I found my own office, I got on the computer myself, got my password, went to IT, I mean I went round and did stuff and I sat there thinking well I wonder what they want me to do (laughter) and I think she'd forgotten that I'd started (P20, University 3)

This absence of more direct hierarchical governance was difficult for participants as it impeded their ability to engage with academic practices, understand systems and processes, and elevated stress as participants were left to their own devices - "dumped" (P6, University 1) and "thrown in" (P13, University 3). In short, they were abruptly 'responsibilised', becoming objects of surveillance that were expected to comply with implicit disciplinary norms that they did not fully understand, hoping to avoid mistakes and creating problems for their own academic careers or their employing universities:

So I guess a lot of the time, you know, you're kind of engaging in complex systems and new processes just with your fingers crossed, hoping you're doing it right because there is never any opportunity for supervision... (P11, University 5)

Yet mistakes did occur, which carried risks for all concerned as lack of knowledge of university policies and process could be harmful for social work students and jeopardise individual and institutional reputations:

The one I remember vividly was... a student who was very seriously ill and applied for extenuating circumstances and...rang me 2 days, and got extenuating circumstances, rang me 2 days after the August re-sit board saying when should she re-submit her work, and I didn't know that nobody would tell her that she had got her extenuating circumstances... and I was her personal tutor, I hadn't looked, she hadn't looked, she had to repeat the year. So that was quite a serious gap in my knowledge (P5, University 5) 
This 'gap' and lack of gaze was articulated as a failing of interpersonal relations; i.e., of "technologies of relationships" - "nobody took control" (P4, University 5). Participants recalled similar frustrations with the lack of observation and assessment of their teaching practices, which hindered their effective engagement with institutional systems and forms of pedagogical practice that were at times in tension with the norms of social work education. The universities' requirement for academics to have or obtain formal higher education teaching qualifications was regarded as beneficial for developing pedagogical skills and enhancing career development opportunities, while teaching and learning also proceeded within specific and ritualised, processes and practices (e.g., electronic submission of student work and predefined marking timescales; quality assurance; specific formulae for writing learning outcomes; admissions processes) that were designed to meet specific neoliberal requirements for "teaching excellence", "student satisfaction" and competition in university league tables ${ }^{55}$ and the National Student Survey, but not necessarily "fitness for practice".

Similar tensions also impeded research skills development, which is essential for recognition of professional value within the UK's national Research Excellence Framework ${ }^{56}$ (hereafter, REF) and another known problem for practitioner academics ${ }^{57}$. While research was not a central feature of most participants' daily practices, the threat of not being submitted for the REF was a powerful "dividing practice" 58 as it exposed individuals to risk of exclusion from a highly valued and rewarded dimension of academic practice. As one participant remarked,

You'll probably have some in your sample where the ethos at their university is not as research intensive as it is here. Erm, but I think that is the reality here, there is this...voice behind you saying, you must publish, you must publish, and if you don't publish, you're not worthy to be in the job. (P16, University 4)

A lack of propitious support deterred and undermined social work academics' confidence in engaging with research and led to difficulties meeting research governance expectations.

I'd applied for this grant... it was, it was the biggest learning curve on applying for grants and university life, because... I'd contacted...one of the senior people in the

\footnotetext{
${ }^{55}$ Andy Hagyard, "Student Intelligence: Challenging Received Wisdom in Student Surveys," in The Future of Higher Education: Policy, Pedagogy and the Student Experience, ed. Les Bell, Howard Stevenson and Mike Neary (2009), 113.

${ }^{56}$ Mark Olssen, "Neoliberal competition in higher education today: research, accountability and impact," British Journal of the Sociology of Education 37:1 (2016), 134-139; Simon Warren, "Struggling for visibility in higher education: caught between neoliberalism 'out there' and 'in here' - an autoethnographic account," Journal of Education Policy 32:2 (2017), 136-137.

${ }^{57}$ Jean Murray, The Findings of the ESCalate Study on Teacher Educators' Induction into Higher Education (2006), 5; Jennifer Harrison and Frankie McKeown, "The Formal and Situated Learning of Beginning Teacher Educators in England: Identifying Characteristics for Successful Induction in the Transition from Workplace in Schools to Workplace in Higher Education," European Journal of Teacher Education 31:2 (2008), 157; “Developing a Research Profile," 250-251, 253.

${ }^{58}$ Michel Foucault, “The Subject and Power," Critical Inquiry 8:4 (1982), 777.
} 
department, the director of social work or whatever, to sign off...this form that had to be sent in and I ended up, four days before the submission was due... being asked well, ...have you, have you gone through faculty approval, have you gone through this, that and the other and it was like there was about a month's worth of work that I hadn't done to prepare to apply for this grant, but I'd not ever applied for anything like that before...so, yeah afterwards got the comments well how would you have known, of course you wouldn't have known...so we shouldn't have assumed that you did. (P17, University 4)

Only one institution had a clearly articulated developmental route for doctoral studies that provided some level of gaze for research skills development. Rather than being hierarchically governed, therefore, the process of becoming research active was haphazard, fortuitous and not accessible to all, which obfuscated institutional decisionmaking processes and increased the risk of being excluded from a key dimension of academic practice. As one participant noted,

...again, it was sheer luck as it, even after we'd been here like a year, just a random email came and both my colleague and I ended up doing a two-year project, working in (Eastern Europe), but that was just sheer luck, there wasn't any planning. (P4, University 5)

The perceived lack of gaze also had a detrimental effect on decision making:

I went to meet with this woman and she could only fit me in at a lunchtime because she was working at home and she came and she arrived and I'd never met her before, she was a member of staff, and I said 'oh we're teaching this module together' and she said 'oh no, I've changed my mind, I don't want to teach it, sorry I can't talk to you... now, I've got to go home because I've got some mince pies in the oven.' And what I couldn't get used to was the fact that the way she'd negotiated with this, and the way that people could do this, that people could literally come in say 'oh I don't want to do it anymore' and you would be left holding that module. (P4, University 4)

This apparent lack of hierarchical observation ${ }^{59}$ both impeded participants' understanding of academic disciplinary regimes and excluded them from the requirements of academic practice, sometimes with enduring effects on careers. While the removal of direct surveillance mechanisms might arguably be empowering, this "lack of gaze" was conversely debilitating as social work academics were responsible for specialised knowledge that they had not previously encountered and felt punished for not conforming to normalising judgements whose logics they did not understand. Participants found themselves working within a "carcerality of incompetence" in which their practical competence and effectiveness as academics were impaired by the absence of gaze, which situated them outside the normalised expectations of academic practice. The effects of this carcerality were most profound during the early stages of their

${ }^{59}$ Discipline and Punish, 170-177. 
academic careers, although its reach pervaded through the risk of being "branded" 60 as not engaged with research and, given the importance of research in academic careers ${ }^{61}$, therefore not "genuine academics" 62 .

\section{Times and spaces of academic life: the "control of activity" and "art of distribution"}

Disciplinary regimes were additionally regulated by the "rhythm" of the academic year and its many timetables and time-regulated regimes, through which "time penetrates the body and with it all the meticulous controls of power"63. As one participant said,

... I don't know if it's the same in every university, but...there's something about you don't know what you don't know until you find out that you didn't know it. And I think that's seems to be, that's what people had said to me oh you'll get used to the rhythm of it. (P17, University 4)

In addition to being "driven" by organisational routines, participants also experienced an "exhaustive use" 64 of time that is reminiscent of the army or factory in which "one must seek to intensify the use of the slightest moment" in order to "tend towards an ideal point at which one maintained maximum speed and maximum efficiency". ${ }^{65}$ Examples include the use of precise formulae to allocate academic workloads and requiring academics to account for all aspects of their work using tools such as the 'Time Allocation Survey' (TAS) and 'Transparent Approach to Costing' (TRAC). ${ }^{66}$

But the guidance that has just come through, the contract you have, you know, that specifies what they, what their expectations are of you, through your workload planning hours which, ...show that you do 550 hours direct contact and 1500 hours of whatever else they think...you know, is acceptable, you know gets bunged in those 1500 hours. (P13, University 3)

While "work intensification" 67 and long working hours ${ }^{68}$ are typical of academic life, the pace of this rhythm appeared to offer no respite; according to one participant, everything happens very quickly, or it feels like it does - a constant round of marking and teaching (P6, University 1). All available time, including leisure time and holiday periods, was

\footnotetext{
${ }^{60}$ Discipline and Punish, 199.

${ }^{61}$ Lisa Lucas, The Research Game in Academic Life (2006), 3.

${ }_{22}$ "Higher Education Change", 128; "New Lecturers," 71; "Identity Work," 425.

${ }^{63}$ Discipline and Punish, 152.

${ }^{64}$ Ibid, 154.

${ }^{65} \mathrm{Ibid}$.

66 "TRAC Data," Office for Students, accessed June 21, 2019, https://www.officeforstudents.org.uk/data-andanalysis/trac-data/; "TRAC Case Study: Academic Time Allocation, Statistical Method," TRAC, accessed June 21，2019， https://www.trac.ac.uk/wp-content/uploads/2018/07/TRAC-case-study-Academic-timeallocation.pdf

67 Joëlle Fanghanel, Being an Academic (2012), 22.

${ }^{68}$ Gina Anderson, “Carving Out Time and Space in the Managerial University," Journal of Organisational Change Management 19:5 (2006), 581; Ann E. Austin, “Expectations and Experiences of Aspiring and Early Career Academics," in Becoming an Academic: International Perspectives, ed. Lynn McAlpine and Gerlese Åkerlind (2010), 27.
} 
consumed by unrelenting demands of academic work, intensive teaching and student care left little time for research, and participants spoke of their need to be constantly available.

"it just keeps going and it never stops and we, you know and I know, it all bleeds out into evenings and weekends and what have you" (P20, University 3).

I'm on emails at weekend, ICT has actually affected all of us and so we're getting into... a norm of, of 24/7 working, which I actually think is deeply unhealthy. And it's affecting us across the board and then it doesn't matter whether you're a social work academic, a social work practitioner, social scientist or anything else. So we are all caught up in this trap and it is another example of, of Giddens juggernaut basically.... (P19, University 4)

This total occupation of time posed risks to participants' health ${ }^{69}$; one commented on health problems due to the exhaustive demands of the neoliberal university coupled with examination from HCPC during a programme re-validation processes.

...you see, for a long time, until, until last year or until the last year, when my stress management strategies broke down as a result of HCPC and being programme manager and being co-opted into so many things that I really didn't know whether I was coming or going. No, more than that, more than that, the worst time in my life, my working life ever, has been in the last year... ...And it literally broke down on me about a year ago because I had to work every single evening as well as every weekend I was working. I worked and worked and worked and worked and more came my way every day, every week, every whatever. To the point where there were no stress management strategies in place anymore. There was no sleep in place anymore (P19, University 4)

These temporal regimes of neoliberal academia created regimented, exhausting and timeconsuming routines, yet the participants of this study were also driven to decode and master them, thus becoming "docile bodies" 70 within a system of temporal power that they felt trapped within.

So too was their experience of space in the academy. The use of space in powerful institutions, or in Foucault's terms the "art of distributions", 71 is a key mechanism of carceral practice. Social work academics' experiences of space in the neoliberal university suggested problematic practices of "partitioning", in which the space of activity is delineated such that everyone "has his [sic] own place" that can be established and calculated, and there is little opportunity for collective action. ${ }^{72}$. Social work academics experienced partitioning in relation to allocation of physical (office) space, but, furthermore, participants conveyed experiences of a type of "solitary confinement" and isolation associated more broadly with the experience of academic practice that was especially problematic at the beginning of academic careers, but could persist. Academic

\footnotetext{
${ }^{69}$ Anderson, “Carving Out Time," 580.

${ }^{70}$ Discipline and Punish, 135.

71 Ibid., 141.

72 Ibid., 143.
} 
labour was characterised by high levels of individualised practice that left some feeling isolated, despite being told that this was in fact a condition of academic success:

I mean, I have been told by a number of academics in the School that actually the only way you'll ever succeed in doing a part-time doctorate in the current environment is to be really bloody minded and just take the time and say no to other things, but I find it very difficult to do that.... but I guess I'm going to have to start doing that if I want to do the doctoral programme. (P11, University 5)

While some argued that working in this way had the potential to facilitate creative practice - saying, for example, "I think one of the strengths is that I'm given a great deal of freedom really in terms of how I structure and how I approach that... and I find that quite rewarding, because you can be quite innovative and quite creative" (P11, University 5) - for many, being placed in individual office space or "partitioned"73 from others intensified the "carcerality of incompetence" by removing opportunities to learn about disciplinary regimes from others with more institutional experience. The use of shared office space, on the other hand, accelerated their learning about the logics of disciplinary regimes and provided opportunities to create a more "compensatory" gaze.

... I think one of the peculiarities of the social work team is that... and this is partly to do with physical space and the organisation of the office, I felt quite remote from the admin people; now, in the local authority setting, I'd always worked very closely with the admin staff and that didn't seem to... it wasn't that it wasn't available, it didn't happen spontaneously in the same way, partly due to the fact that we'd not been on the same floor as them and that sort of thing. So, usually in the local authority there would have been someone within shouting distance, if you like, you know, that you could say 'well how does this work and what should I do with this?' So I suppose that was possibly a sort of downside of the, being in your own office, and people working quite separately. (P2, University 5)

Academics work very much in isolation...I mean look at me, I have my, I have my own office, I have my own module, I have my own teaching sessions, everything is very, in chunks... and that's why I sometimes feel it's like being self-employed, you have your little bits to manage and that becomes your main focus then.... I...we rarely have big team meetings.... (P16, University 4$)$

As with time, therefore, practices of spatialisation (particularly partitioning and experiences of solitary confinement) were not only common in academic practice but also constitutive of the "carceral networks"74 that excluded social work academics understanding and demonstrating competency in academic practice.

\footnotetext{
73 Discipline and Punish, 143.

74 Ibid, 298.
} 


\section{Academic performance or social care? Negotiating competing normalising judgements within a neoliberal disciplinary regime}

According to Foucault, the process of normalisation regulates subjects' bodies and lives by normalising certain behaviours and abnormalising those constructed as outside of societal norms ${ }^{75}$ that categorise individuals into 'in' and 'out' groups. In this study, social work academics found themselves situated in the crosshairs of competing discourses of normalising judgement. Each system incorporates “...the binary opposition of the permitted and the forbidden; not by homogenizing, but by operating the division, acquired once and for all, of condemnation. The disciplinary mechanisms secreted a "penality of the norm"76. By having clear rules and expectations, normalising judgements of different disciplinary settings (here, education and social work) provide “...a whole range of degrees of normality indicating membership of a homogenous social body but also playing a part in classification, hierarchization and the distribution of rank."77

Specifically, while norms for both academic and social work practice were constituted as forms of broad neoliberal discipline, particular discursive requirements for success, belonging and professional legitimacy were oriented towards different and sometimes competing objectives. Social work academics' strategic and situated acceptance and rejection of the legitimacy of these judgements highlights the possibilities for agency within the specialized institutions comprising complex disciplinary regimes. While Foucault argued that each institution and discipline would have a disciplinary system which created norms and expectations by way of "micro-penalties"78 and "...a double system: gratification-punishment"79, his work also clarifies how subjects formed within and across multiple disciplinary institutions may navigate the tensions this can create. Following Ravinder Kaur Sidhu, it allows us to see how "at any one time, there will be a multiplicity of discourses, some competing or in tension with each other, and others in relationships that are broadly reinforcing" and that "it is this multiplicity which opens space for resistance." 80

For example, certain norms of defining academic practice as business and students as consumers were, superficially at least, accepted as reality by participants. Some welcomed a focus on teaching associated with tuition fees:

they, if you like, I know that's a bit dramatic, they pay my wages and so I think we should ensure that they have the best learn(ing), teaching and learning opportunities. (P4, University 5)

Others valued competing for admissions and the motivating power of "student satisfaction".

\footnotetext{
75 Discipline and Punish, 177-184; Laura Epstein, "The Culture of Social Work," in Reading Foucault for Social Work, ed. Adrienne S. Chambon, Allan Irving and Laura Epstein (1999), 9.

76 Discipline and Punish, 183.

77 Ibid., 184.

${ }^{78}$ Ibid., 178.

79 Ibid.

${ }^{80}$ Ravinder Kaur Sidhu, Universities and Globalization: To Market, to Market (2006), 28.
} 
"(Place) University is our biggest competition and they are a very popular and very well liked university, so I think we've just got to, for want of a better phrase, pimp ourselves out a bit more" (P6, University 1).

But as well as that, there are extrinsic drivers for that in terms of the National Student Survey as well, that's a, that's a reality. If we have unhappy students, they then go on that survey, which is then published, which makes us look like we're not doing a good job, so we need to make sure that we are. (P16, University 4)

However, there were limits to the acceptance of this dimension of the neoliberal agenda. This was particularly pronounced in the context of the UK's "student as consumer" agenda, which by increasing expectations about supporting student progression, intensified longstanding concerns within social work that academics would be unable to fail students who were unsuitable for social work practice ${ }^{81}$. To disrupt this, service users, not students, were regarded as the primary consumers of social work education. Student suitability for the profession and protection of the public (both of which are the objects of normalising judgements within social work practice) were prioritised over higher education agendas as social work academics made strategic choices between conforming to the evaluating demands of competing normalising judgements. In this case, the normalising judgements of higher education clashed with those of social work and particularly those reproduced by social work academics themselves as "gatekeepers to the profession". As one participant said,

...the, the admin role is definitely...walking a tightrope between two very, very clear influences which is, which is the, the university, the demands of the university... and, and all of, all that that represents in terms of getting student numbers in and finances and stuff, and, and, what I would always want to be a tension with that, a very, very clear tension with that, which is my responsibility to the profession....to HCPC, we've got a, we can't, we can't and I won't, be... be led to the position where I'm only listening to the university because we've got, and should have, our feet in both camps. To have a responsibility to your employer is fair, but..., I will always...have the professional integrity as the highest context marker and that is going to be something that if it has tension in it, that I, that I'll dig my heels in on, because that's the highest context marker and there's no way that that can be compromised. So that's, in an admissions role, that's really, that can be really challenging when people want student numbers in, but I'm not signing my name against somebody I don't think should be on this course whether you want $£ 9000$ from them or not. (P17, University 4)

And in the words of another at the same university

...I sit in module boards sometimes and students can submit mitigating circumstances forms for every piece of work and keep failing, but because of the mit circs are upheld...how far would an employer think it's right that a student should take to pass

\footnotetext{
${ }^{81}$ Jo Finch and Imogen Taylor, "Failure to Fail? Practice Educators' Emotional Experiences of Assessing Failing Social Work Students," Social Work Education 32:2 (2013), 245.
} 
a social work with children and families module...what would their view be of that? We can have students with having 3 or 4 attempts, fail that, come back and re-sit the module. Fail one attempt, pass at the next attempt, that's essentially 6 attempts, you know, if, we don't have any end to how far students can submit a mits circs form and keep getting new first attempts...but that's the university regulation that we have to abide by. Does that fit with someone being fit to practise, I'm not sure. (P16, University 4)

Research was similarly subject to the dissonant normalising judgements of higher education and social work practices. Whilst there were overt attempts among the participants of this study to engage with academic research, there was also rejection of, and ambivalence towards, "blue skies" research that had no discernible benefits for service users or practical application.

...it's just self-serving, it is about meeting the needs of the university, it's about bringing money in the door, it's about the next journal article, the next book, the next conference, I very rarely see any meaningful change, I don't see the lives of students, the lives of service users, significantly improving as a consequence. It seems that some really innovative and student-centred projects are kind of borne out of research, but as soon as research ends, the project disappears, practice disappears. And to my mind, the integrity of it, I question. If, if I had a choice of, the only research doing that kind of research, I'd rather not do any research because I think it's dishonest...maybe my value base shapes too much and constricts what I do, but I make no apologies for it... if I do research, I do want it to make a difference really, I want it to be for a purpose other than just getting another journal article out of it. (P11, University 5)

Becoming research active was especially problematic ${ }^{82}$ for those working in institutions driven by pressures to publish but who tended not to have $\mathrm{PhDs}$ or academic publications, which some saw as being central to being a "real" academic (only one participant in this study was eligible to submit their work for the $2014 \mathrm{REF}$ ). As one recounted,

there's a sense that, for me, this is the beginning of the mechanism to try and...cut out some of the... sort the wheat from the chaff. And with not being submitted for the REF, I do feel an acute sense that I might be, be seen, by some of the powers that be here, as one of those potential members of staff, that hasn't been submitted. I have produced 4 outputs...but again, in terms of the points mean prizes thing, a couple of those are book chapters...they don't carry as much weight as single authored journal articles in peerreviewed journals...so there's a sense, I do feel a sense of something's afoot...you feel vulnerable if you're not publishing outputs. (P16, University 4)

In other words, when normalised expectations within higher education and social work conflicted, and they often did, participants used technologies of the self to exercise agency

82 Harrison and McKeown, “The Formal and Situated Learning," 157, 160; "Developing a Research Profile," 250-251. 
in the strategic reproduction and disruption of competing normalising discourses. Technologies of the self which enable social work academics to recognise and select between the conflicting normalising judgements of higher education and social work, with those relating to care for service users in social work (e.g., service users) often being prioritised. There were a variety of ways to resist the normalisation of neoliberal agendas in social work education, including leaving jobs and using academic practice to reformulate and challenge neoliberal "technical-rational" 83 discourses evident in social work. This resistance further reframed discourses, creating alternative "regimes of truth" 84 that focused on the needs of service users and resisted the pressures of managerialism.

And the difficulty is that when you then start to look at the kind of social workers that employers are demanding we churn out, against the definition proffered by the International Federation of Social Work, it bears little or no resemblance. And we are criticised and I think we are strong enough to go back and challenge the criticism from employers that we are not turning out the kind of social workers that they want. But I think the day we start to lose sight of what social work should be about, it's about holistic practice, it's about developing people as part of complex systems, rather than just bits of their lives, then we might as well give up and pack in because increasingly within the statutory sector, employers want us to churn out procedurally driven, mechanistic practitioners. (P11, University 5)

An understanding of the neoliberal norms of social work practice and the inbuilt surveillance and control therein highlights the contrast between professional social work practice and higher education - and thus why the transition for social work academics was often experienced as "a lack of gaze", which compromised their own role as disciplinarians and "guardians of the profession".

\section{Examination}

Far from being only subjects of normalising judgements as neoliberal academics, social work academics also imposed normalising judgements on others - their students. The process of examination draws together being observed with normalising judgements. ${ }^{85} \mathrm{It}$ introduces an evaluative element to the normalisation process and is a means to construct and disseminate knowledge. The social work academics interviewed for this study were both examiners and examinees. Through surveillance, they examine students by assessing their academic work ${ }^{86}$ and making assessments and decisions about students' fitness to practice; as one put it, "we have to not only guard the academic, but the profession as well" (P4, University 5). Social work students therefore experienced multiple layers of examination, some of which regulated access to social work degree courses. Yet social work academics

\footnotetext{
${ }^{83}$ Eileen Munro, The Munro Review of Child Protection: Final Report - A Child Centred System: CM8062 (2011), 86.

${ }^{84}$ James D. Faubion (ed), Power: Essential Works of Foucault 1954 - 1985 Volume 3 (1994), 132.

${ }^{85}$ Discipline and Punish, 184.

86 "The Panopticon," 729.
} 
were also examined, with standards of practice being judged partly through processes of higher education governance (such as course validation panels and ethical approval processes, and research assessment) ${ }^{87}$ and partly by the regulatory body (HCPC). At the time of data collection, the College of Social Work (now obsolete) specified the requirements of the curricula and imposed expectations of professional behaviours, attitudes and skills on individuals as registered social workers. The HCPC has a mandatory registration and renewal process where social work academics must evidence compliance, and to which they feel accountable; as one participant said, "but the HCPC...I've been to training... about that, you know, to make sure that we know about the codes of conduct and what their expectations are..." (P14, University 3).

Less overt, but still evident, was the examination of employers by social work academics, particularly in relation to practice education and student placements.

... I've read some stuff where you think 'what you've been doing for the last three years?' but equally I've read, you know, several portfolios and I've just thought 'that is fantastic practice' you know what a great agency (P9, University 5)

However, processes of examination with employers/placement providers were reciprocal as external agencies exerted examination and influence on academic practice "Our partner agencies influence what we do" (P10, University 2). Moreover, within social work student work placements and in qualified social work practice, service users become the objects of examination mechanisms.

Foucault ${ }^{88}$ proposed that examination is rife with power, hierarchical and typically onedirectional. However, this study indicates that within neoliberal universities in England, although hierarchical examination had the most potent influences, examination disciplines in several directions. For while social work academics were the objects of various forms of examination, they were also central to exercising some examination practices to discipline others. As one participant remarked, I think we are guardians of the profession... (P4, University 5).

Acting as gatekeepers within the admissions process and by being actively involved with failing students and fitness to practise hearings, and seeking to make their students employable, social work academics were positioned as "guardians of the profession". This reflected non-academic normalising discourses, perpetuated by government, inquiries into service provision and ongoing educational reforms ${ }^{89}$ about preparing students to

\footnotetext{
87 “Academic Assessment," 79-81; “The Panopticon,” 729.

88 Discipline and Punish, 184.

${ }^{89}$ Lord Laming, The Protection of Children in England: A Progress Report (2009); Patrick Butler, "How Alan Wood Became the 'Go-To Fixer' for Child Protection," The Guardian, July 9th, 2014. https:/www.theguardian.com/society/2014/jul/09/alan-wood-go-to-fixer-child-protection-hackney-socialwork; "Grant Determination Letter for Social Work Teaching Partnerships," Department for Education, June $28^{\text {th }}$, 2019 , https://assets.publishing.service.gov.uk/government/uploads/system/uploads/attachment data/file/685888/ 3236 - SOCIAL WORK TEACHING PARTNERSHIPS 2017-18 - S31 - DFE -

Grant Determination.pdf
} 
become qualified practitioners, particularly in children's services ${ }^{90}$. Actively engaging with this normalising practice was underpinned by a focus on promoting the wellbeing of service users.

....and I do say if any of you are here for the money, you can forget it now because social work is not about that...you're not going to get that well paid actually, if you want money, go into business or something, but no, hopefully you're not here for the money. I say it jokingly but in my heart, I'm thinking, yeah I want the right kind of person here really (P14, University 3)

Reflecting critically on the dominant normalising judgements of the professor was therefore a significant factor in social work academics' work to "guard the profession" through normalising students' subjectivity and behaviour. Social work academics normalised students' behaviours, moulding them as nascent professionals by influencing future social work practice, "I feel quite honoured that I can have some influence in that" (P8, University 5), and promoting specific methods or values. Students are prepared for the complex demands and challenges of social work practice, now embedded as a specific priority of government-funded social work teaching partnerships. As one participant remarked,

I can't let somebody go out there knowing that they're not ready for that, we haven't somehow built those skills. So, that keeps me going, it sounds very altruistic and I don't want it to sound like that but it, it's what guides me in terms of firming me up in terms of sound values, sound knowledge, you know, how do you evidence, how do you make somebody who sits in their first year, who thinks it's fine to sit there reading fifty shades of grey because it's a great love story even though it's about bondage and abuse of women, to actually get to the point of thinking well actually I have to think about that because over here I might be working with women who have been abused, both sexually and emotionally, and actually this is really derogatory when I'm thinking about that. (P13, University 3)

On a more coercive level, participants actively enforced expectations about professional behaviours and values, fitness to practise and the requirements of the profession's regulatory body ${ }^{91}$. They explained regulatory requirements to students, oversaw behaviours through hierarchical observation and examination, and intervened in capability issues or breaches of professional standards, thereby actively policing professional expectations and taking action that could terminate students' studies. This created tension between norms in higher education, such as facilitating student progression and relating to students as consumers on the one hand, and those of social work (protecting the public) on the other. In short, social work academics navigated their

90 Laming, The Protection of Children, 88; Social Work Reform Board, Building a Safe and Confident Future: Maintaining Momentum (2012), 29-30, https://assets.publishing.service.gov.uk/government/uploads/system/uploads/attachment data/file/17 5947/SWRB progress report - June 2012.pdf

${ }^{91}$ Health and Care Professions Council, Guidance on Conduct and Ethics for Students (2016), 10-15. 
way through the demands of various normalising judgements, accepting some, enforcing social work norms, rejecting others and trying to find a way to navigate between competing judgements. The complexity of this practice is illustrated schematically in Figure 2.

\section{(NOT) BECOMING ACADEMIC: TECHNOLOGIES OF SELF AND RELATIONSHIPS}

Social work academics responded to this form of carcerality in part by developing "technologies of the self" that, while enabling them to become competent neoliberal academics, also deepened the carceral elements of social work education. Some participants noted that their "core" social work identity was irrevocably entwined with a self that preceded and superseded the norms of neoliberal higher education.

But I live, breathe, this sounds a bit sort of magnanimous, but I do live and breathe by social work ethics and then what I do is transfer them into academic life, you know, so. You know, so, I don't go out of here at 5 o'clock and think job done, you know, I'm going home, you know, I would like to think that and I think that's probably what most social workers would do, you would hope so anyway (P21, University 3)

Similarly, when higher education norms (for example, about writing) were integrated into social work academic identities and practices, this was done as a way of "taking care of self" 92 within the neoliberal system. Participants engaged with custom and practice in higher education by aspiring to traditional academic qualifications such as the doctorate, ${ }^{93}$ self-evaluating their own research output and performance, and developing futurefocused research ambitions. As one remarked,

I was expected to undertake my (name of course) which is post-graduate certificate in lecturing and teaching and then move on to my MA and, with the expectation that once my MA is completed at the end of this year, I will be enrolling onto my doctorate. So there is almost the expectation that you will continue your professional development as well. (P13, University 3)

While all of these (reflecting Foucauldian technologies of the self in the form of "knowing yourself" 94 and meditation/askesis ${ }^{95}$ ) enabled participants to survive the performative university, they also learned to entrap themselves within the performative regime through these practices. Yet there was also rejection of some carceral elements of higher education practice in the form of negotiating competing normalising judgements, even

\footnotetext{
${ }^{92}$ Michel Foucault, "Technologies of the Self" [1982], in Technologies of the Self: A Seminar with Michel Foucault, ed. Luther H. Martin, Huck Gutman and Patrick H. Hutton (1988), 19.

${ }^{93}$ Johanna Hakala, "The Future of the Academic Calling? Junior Researchers in the Entrepreneurial University," Higher Education 57:2 (2009), 179; Lynn McAlpine, Cheryl Amundsen and Marian JazvacMartek, "Living and Imagining Academic Identities," in Becoming an Academic: International Perspectives, ed. Lynn McAlpine and Gerlese Åkerlind (2010), 129.

${ }^{94}$ Foucault, "Technologies of the Self," 26.

${ }^{95}$ Ibid., 35-36.
} 
where these remained significantly influential in disciplining actions and behaviours. This alternative engagement was enabled by more collective "technologies of relationships." These served first to facilitate the entry of social workers into the academy, and second to reduce the risk of professional error and provide support once they arrived.

Interpersonal relationships were in operation prior to academic employment as participants were informed of job vacancies, convinced to apply for posts and on occasion offered employment opportunities. As one participant remarked, “...by sheer coincidence, a colleague, another colleague, had rang me and said, do you know there's a job going at the university and you'd be brilliant" (P18, University 5). One consequence of facilitating academic employment in this way is that it may create closed communities which permit some to enter and discourage others ${ }^{96}$. In two of the universities in this study, participants discussed the exclusionary effects of such relationships, such as the rejection of non-social work academics or positioning people as outsiders, which reinforced the experience of solitary confinement.

....and in academia there is a bit too much autonomy, that people can...co-teach, coresearch and arrange to co-work admin tasks with who they choose. That means that certain people, particularly people like me who come from the outside, they don't get used to co-working with, by definition, and if they only ever co-work with the person they trained with, the person they practised with and in some cases, the person that they're involved in a romantic relationship with...they don't extend their horizons (P19, University 4)

Well, there's been people who work here but people have thought actually that they've got nothing to contribute, they've got no real social work knowledge, they're just here because they've got their $\mathrm{PhD}$, they're just here because the person who interviewed them is a friend of theirs, we're going to blank them and ignore them and then they either leave or they stay but don't really integrate with the team or the team changes their mind and accepts them as a member...There's people who we socialise regularly and are very happy and friendly with and who are our friends who when they first came here everyone said don't know why they've employed them, they're only employed because they are a friend of the person interviewing and they are rubbish, they've got no practice... Then you've got other people who we've practically drummed out of the place (P7, University 5).

On arrival in academic employment, relationships continued to play an important part of the transition process, being used to create a "compensatory gaze" in the absence of direct hierarchical observation and to explain academic practice and the expectation of the disciplinary regime, constituting a pragmatic solution to professional survival in academic systems which have the "power to punish"97 yet do not make the criteria for being 'good academics' accessible to newcomers who are evaluated on them. Because of

\footnotetext{
${ }^{96}$ Penny Noel, "The Secret Life of Teacher Educators: Becoming a Teacher Educator in the Learning and Skills Sector," Journal of Vocational Education and Training 58:2 (2006), 167.

${ }_{97}$ Discipline and Punish, 303.
} 
its informal (i.e., collegiate rather than managerial) nature, this compensatory gaze did not function as a controlling surveillance mechanism, although there were instances where it was used more formally, through mentoring systems, to support development. However, as this often happened between new academic staff who did not have experienced knowledge of working in higher education, this gaze nevertheless reproduced the effects of the carcerality of incompetence.

"there was somebody to work, to mentor me, in terms of the work that I was doing but I didn't know what to ask" (P5, University 5)

Despite the fact that the creation of this "compensatory gaze" was experienced by the participants of this study as beneficial because it enabled their professional survival within the neoliberal higher education system, it contributed to social work academics becoming "docile bodies" 98 through collective (rather than individual) responsibilisation. Yet this experience also illustrates how the absence of hierarchical observation ${ }^{99}$ can be equally as subjectivating as perpetual observation, as it creates a carcerality of incompetence which threatens to punish individuals who are insufficiently 'responsibilised'. Compensatory gaze "empowers" social work academics with equal opportunities to learn the technologies of the self that are necessary for becoming academic in the neoliberal system by promoting effective engagement with academic practice. This problematises Foucault's ${ }^{100}$ ideas on hierarchical observation. Productive aspects of hierarchical observation have also been reported in research about medical interventions; for example, there are "numerous examples of people affected by cancer reflecting on issues such as power and surveillance in cancer care. While these terms are ordinarily considered to reflect negative elements of care, they were used by participants in an empowering manner". 101

In short, technologies of relationships contributed to a carceral network in several ways; by influencing potential applicants for academic employment, by supporting or limiting opportunities and through their exclusionary characteristics. And, like technologies of the self, interactions with others in the form of technologies of relationships were also double-edged insofar as they supported participants whilst constraining them.

\section{RESISTANCE AND RESPONSES TO CARCERAL DISCIPLINE IN THE NEOLIBERAL UNIVERSITY: INSIGHTS FROM SOCIAL WORK EDUCATION}

Seen through the lens of Foucault's theories of disciplinary power and technologies of self, it becomes apparent that the social work academics who participated in this study were confined within a complex carceral system, pictured in Figure 1, in their new professional lives.

\footnotetext{
${ }^{98}$ Ibid., 135.

${ }^{99}$ Ibid., 170-177.

${ }^{100}$ Ibid.

${ }^{101}$ Forbat et al., "The Use of Technology," 306.
} 


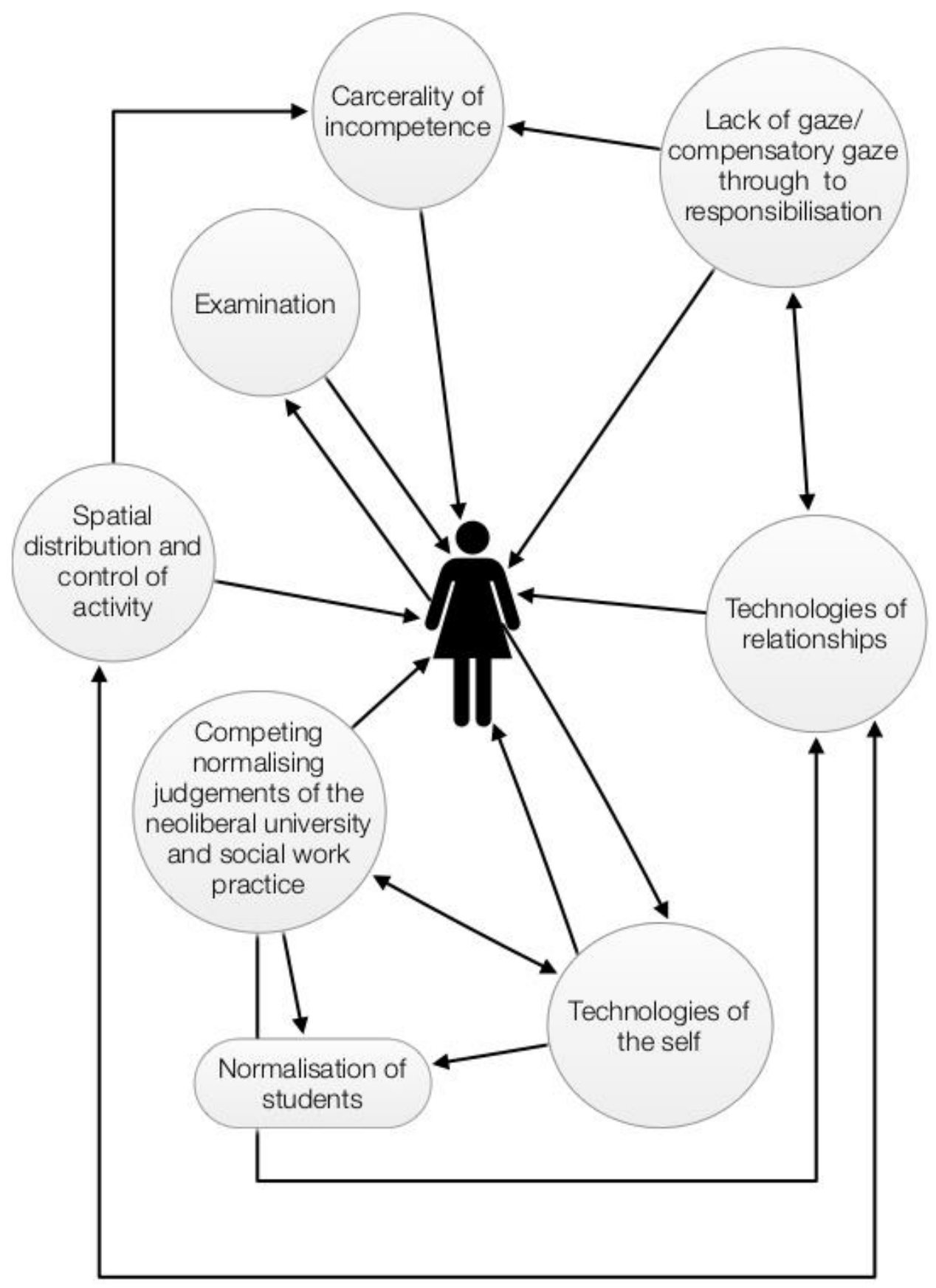

\section{FIGURE 1: The Carceral Elements of Social Work Education in England}

At the same time, however, these concepts are not sufficient for helping us understand either the complexity of the positions they occupied within universities or the possibilities they had for acting strategically on power from within their positioning. By introducing new concepts of "technologies of relationships", the "compensatory gaze" and the "carcerality of incompetence", we have expanded possibilities to apply Foucault's 
theories of discipline in powerful institutions to the experiences of social work academics in neoliberal English universities. In this context, the experience of moving from a profession in which selves are governed through more hierarchical forms of disciplinary power into a "carceral network" 102 of responsibilisation that is experienced as producing "incompetence" is mediated by social work academics through learning to practice neoliberal technologies of the self and new technologies of relationships and creating a compensatory collegiate gaze. Within this process, they are not only subjects of discipline but also subject others to it as they promote and control students' behaviours to conform to the requirements of professional social work practice. While individual agency within this situation is not impossible, it is thus most overtly exercised in choosing between the often competing normalising judgements of higher education and social work practice. Figure 1 provides a diagrammatic explanation of the experiences of carcerality, visually representing the operation of disciplinary power, technologies of relationships and technologies of self and indicating how these combine to create a network that dictates the behaviours of social work academics.

In addition, the study suggests that social work academics can be situated between competing the normalising judgements of higher education and social work practice and that they can, when required, conform to those that prioritise the needs of service users, public protection, and support for the development of skills for front-line social work practice over the economistic requirements of the university. They also acted as gatekeepers to, and guardians of, the profession by actively promoting certain professional norms to shape and direct the behaviours of students, including censoring and disciplining students who did not comply with the requirements of the professional regulator. And, while they accepted that the university operates within a marketised environment in which students are defined as 'consumers', they repositioned service users as the consumers of social work degree programmes rather than students. In other words, they simultaneously adhered to and opposed the neoliberal logics of higher education in England, thus demonstrating that while a governmental system may "structure the possible field of action of others," it does not determine it; that, as Foucault argues, "it would not be possible for power relations to exist without points of insubordination which, by definition, are means of escape."103

Because they were not fully socialised into academic life or 'responsibilised' to recreate themselves as autonomous academic subjects, the participants of this study experienced multiple systems of discipline in operation at the same time. As they could not respond to these by conforming to all, they took on a variety of positions, including "docile bodies", "seditious academics" or "enforcers" of normalising judgements; these are represented in Figure 2 below. Social work academics navigated their way through competing normalising judgements from social work practice and academia through these three positions. For example, they were docile in response to neoliberal academic business models including consumer (student) satisfaction yet simultaneously seditious

102 Discipline and Punish, 298.

${ }^{103}$ Foucault, “The subject and power," 790, 794. 
in response to neoliberal notions of students as consumers of social work education, enforcing norms of service users as consumers of social work education. These positions provided a means to negotiate complex neoliberal influences in higher education whilst retaining social work professional integrity.

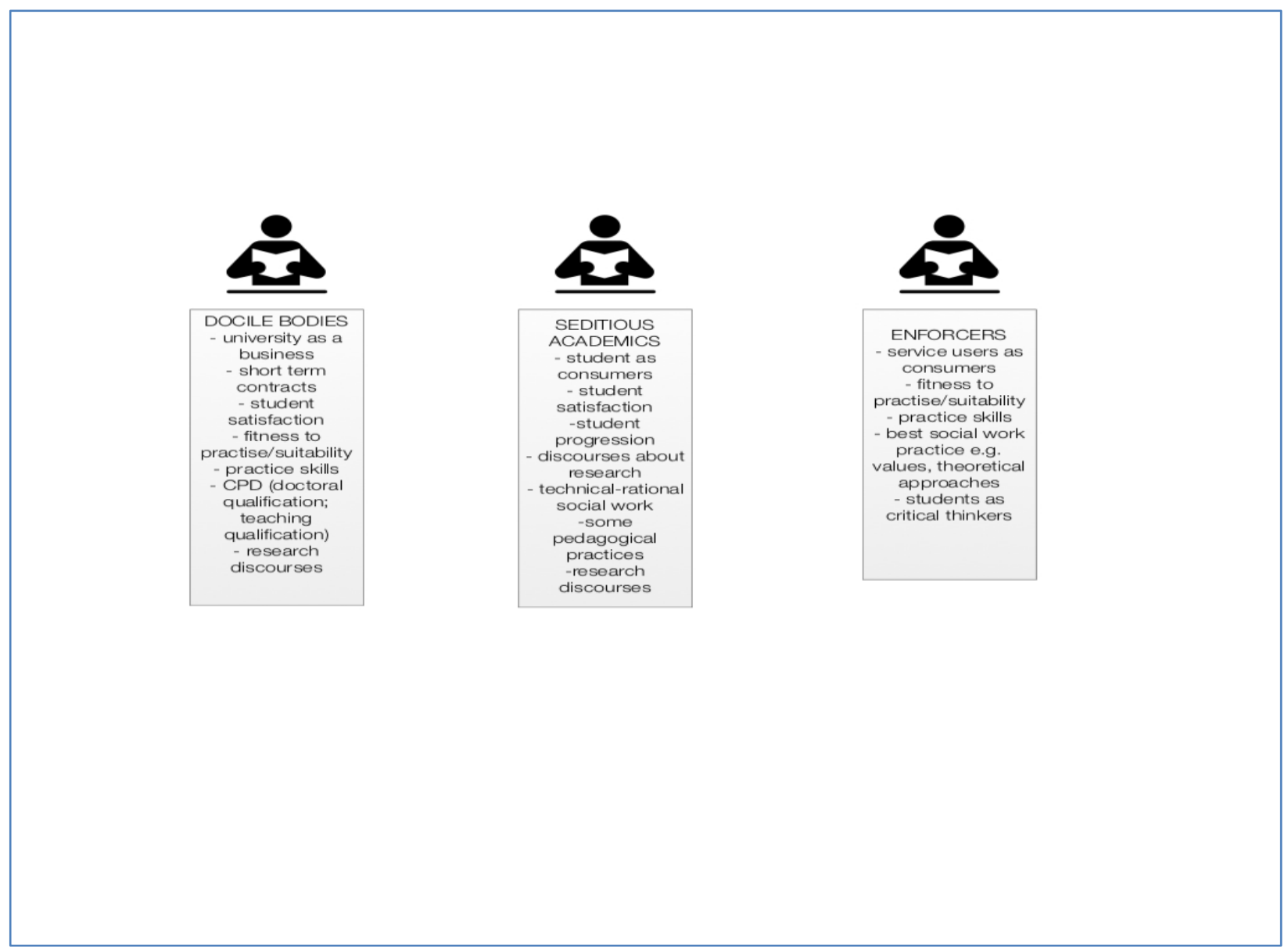

Figure 2: Positions of social work academics in relation to competing normalising judgements

\section{CONCLUSION}

This paper has demonstrated how a form of disciplinary power, as theorised by Foucault, is constructed for and experienced by social work academics in five neoliberal universities in England. The broad finding is that, within this context, social work academics exist within a complex carceral network which is constructed not only through traditional forms of disciplinary power, such as hierarchical observation, examination, use of time and space and normalising judgements, but also through technologies of indirect management or responsibilisation. This is evidenced by participants' experiences of a perceived lack of disciplinary gaze and the construction of a compensatory gaze that simultaneously mitigates and reinforces a "carcerality of incompetence". The carcerality of incompetence arises in a number of ways, including being unable to, or precluded from, 
engaging with academic practices because of a lack of understanding of, and inability to engage with, the norms and requirements of being an academic. This form of disciplinary power is compounded by both the perceived lack of gaze and solitary confinement, and attempts to create technologies of relationships providing a collective compensatory gaze with others who are often equally as unaware of the requirements of academic practice.

The construction of a compensatory gaze is a response which imports hierarchical observation into a responsibilised regime. However, such gaze, operationalised via technologies of the self and relationships, also contains principles of value-based social work practice (collectivism, peer support, solidarity) which have the potential to disrupt practices within the neoliberal university and social work practice as they challenge the individualisation - and at times the questioning and challenging - of responsibilisation through collectivising. Technologies of relationships, whilst contributing to some extent to social work academics being docile bodies, also emphasise the norms of social work practice and offer alternatives to individual responsibilisation by emphasising collective rather than individual responses.

Within the carceral network of academic work, the demands of the neoliberal university, neoliberal social work and the protection of the social work profession and its underpinning values intersect in ways that often cause conflict for social work academics. This occupation of multiple, co-existing and at times conflicting realities, however, presents competing sets of normalising judgements. In being guardians of the profession, for example, social work academics promote ideas about ideal practice and the best interests of service users, based on principles of social justice, which other normalising judgements of the neoliberal university eviscerate. Consequently, social work academics move between these worlds, including that of highly regulated social work practice, while negotiating a responsibilised regime of disciplinary power. This constant movement and positioning in and between these worlds or contexts renders the responsibilisation of power more visible and reveals the inaccessibility of regimes to those incarcerated fully within them.

In providing these insights, this paper provides a foundation upon which social work academics in England can analyse their experiences of and responses to academic practices, in particular how they position themselves in relation to the normalising judgements of both the neoliberal university and neoliberal social work practice. In emphasising collective responses to multiple worlds and identities, individualised academic practices, and the carcerality of incompetence created by responsibilised governance, can be challenged and politicised. It is likely that the experiences of social work academics will resonate with other vocational academic disciplines such as nursing and teaching, as well as with social work academics in other neoliberal higher education systems. Further research is advisable to test the portability and robustness of theconcepts in this paper, particularly those that develop Foucauldian theory such as compensatory gaze, technologies or relationships and carcerality of incompetence. It is likely that they will be relevant to other vocational academic disciplines 


\section{References}

Allen, Chris, "On the Social Relations of Contract Research Production: Power, Positionality and Epistemology in Housing and Urban Research," Housing Studies 20:6 (2005), 989 - 1007. https://doi.org/10.1080/02673030500291132

Amsler, Mark and Cris Shore, "Responsibilisation and Leadership in the Neoliberal University: A New Zealand Perspective," Discourse: Studies in the Cultural Politics of Education 38:1 (2017), 123-137. https://doi.org/10.1080/01596306.2015.1104857

Anderson, Gina, "Carving Out Time and Space in the Managerial University," Journal of $\begin{array}{llll}\text { Organisational Change } \quad \text { Management } \quad \text { 19:5 } & \text { (2006), }\end{array}$ https://doi.org/10.1108/09534810610686698

Austin, Ann E, "Expectations and Experiences of Aspiring and Early Career Academics." in Becoming an Academic: International Perspectives, ed. Lynn McAlpine and Gerlese Åkerlind, 18-44. Basingstoke: Palgrave Macmillan, 2010.

Baxter, Pamela and Susan Jack, “Qualitative Case Study Methodology: Study Design and Implementation for Novice Researchers," The Qualitative Report 13:4 (2008), 544-559.

Blenkinsopp, John and Brenda Stalker. "Identity Work in the Transition from Manager to Management Academic." Management Decision 42:3/4 (2004), $418 \quad$ - 429. https://doi.org/10.1108/00251740410518903

Boyd, Peter, Lily Baker, Kim Harris, Chris Kynch and Emma McVittie, Working with Multiple Identities: Supporting New Teacher Education Tutors in Higher Education. Bristol: ESCalate, 2006.

Bradbury-Jones, Caroline, Sally Sambrook and Fiona Irvine, "Power and Empowerment in Nursing: A Fourth Theoretical Perspective." Journal of Advanced Nursing 62:2 (2008), 258266. https://doi.org/10.1111/j.1365-2648.2008.04598.x

Broadhead, Lee-Ann and Sean Howard, "The Art of Punishing": The Research Assessment Exercise and the Ritualisation of Power in Higher Education," Education Policy Analysis Archives 6:8 (1998), 1-14. https://doi.org/10.14507/epaa.v6n8.1998

Bryman, Alan, Social Research Methods. Third Edition. Oxford: Oxford University Press, 2008. Butler, Patrick, "How Alan Wood Became the 'Go-To Fixer' for Child Protection," The Guardian, July 9th, 2014. https://www.theguardian.com/society/2014/jul/09/alan-wood-goto-fixer-child-protection-hackney-social-work

Clegg, Sue, "Academic Identities Under Threat?," British Educational Research Journal 34:3 (2008), 329 - 345. https://doi.org/10.1080/01411920701532269

Cohen, Michael, I., "In the Back of Our Minds Always: Reflexivity as Resistance for the Performing Principal," International Journal of Leadership in Education: Theory and Practice 17:1 (2014), 1-22.

https://doi.org/10.1080/13603124.2013.804208

Collins, Stewart and Beth Parry-Jones, "Stress: The Perceptions of Social Work Lecturers in Britain," British Journal of Social Work 30:6 (2000), 769-794.

https://doi.org/10.1093/bjsw/30.6.769 
Davies, Bronwyn, "Subjectification: the relevance of Butler's analysis for education," British Journal of Sociology of Education, 27:4 (2006), 425-438.

https://doi.org/10.1080/01425690600802907

Demeo, Stephen, "Gazing at the Hand: A Foucauldian View of the Teaching of Manipulative Skills to Introductory Chemistry Students in the United States and the Potential for Transforming Laboratory Instruction," Curriculum Inquiry 35:3 (2005), 295-338.

\section{https://doi.org/10.1111/j.1467-873X.2005.00330.x}

Department for Education, "Grant Determination Letter for Social Work Teaching $\begin{array}{llll}\text { Partnerships," } \quad \text { Accessed } & 28^{\text {th }} & \text { June }\end{array}$

https://assets.publishing.service.gov.uk/government/uploads/system/uploads/attachmen t data/file/685888/3236 - SOCIAL WORK TEACHING PARTNERSHIPS 2017-18 -

S31 - DFE - Grant Determination.pdf

Dutton, Michael, "Disciplinary Projects and Carceral Spread: Foucauldian Theory and Chinese Practice," Economy and Society 21:3 (1992), 276-294.

https://doi.org/10.1080/03085149200000014

Economic and Social Research Council, An Audit of Baseline Resources for Social Work Research: Finances, Staff, Teaching. Swindon: ESRC, 2008.

Enright, Eimear, Laura Alfrey, and Steven B. Rynne. "Being and becoming an academic in the neoliberal university: a necessary conversation," Sport, Education and Society 22:1 (2017), 14.

\section{https://doi.org/10.1080/13573322.2016.1259999}

Epstein, Laura, "The Culture of Social Work." in Reading Foucault for Social Work, ed. Adrienne S. Chambon, Allan Irving and Laura Epstein, 3-26. New York: Columbia University Press, 1999.

Evaluation of the Social Work Degree Qualification in England Team, Evaluation of the New Social Work Degree Qualification in England: Volume 1: Findings. London: Kings College London, Social Care Workforce Research Unit, 2008.

Fanghanel, Joëlle, Being an Academic. London: Routledge, 2012.

Faubion, James D, (ed). Power: Essential Works of Foucault 1954-1985 Volume 3. London: Penguin Book, 1994.

Field, Sue, "The Trials of Transition, and the Impact Upon the Pedagogy of New Teacher Educators," Professional Development in Education 38:5 (2012), 811-826.

https://doi.org/10.1080/19415257.2012.701658

Finch, Jo and Imogen Taylor, "Failure to Fail? Practice Educators' Emotional Experiences of Assessing Failing Social Work Students," Social Work Education 32:2 (2013), 244-258.

https://doi.org/10.1080/02615479.2012.720250

Findlow, Sally, "Higher Education Change and Professional-Academic Identity in Newly 'Academic' Disciplines: The Case of Nurse Education," Higher Education 63:1 (2012), 117133.

https://doi.org/10.1007/s10734-011-9449-4 
Fisher, Mike and Peter Marsh, "Social Work Research and the 2001 Research Assessment Exercise: An Initial Overview," Social Work Education 22:1 (2003), 71-80.

https://doi.org/10.1080/02615470309128

Flint, John, "The Inspection House and Neglected Dynamics of Governance: The Case of Domestic Visits in Family Intervention Projects," Housing Studies 27:6 (2012), 822-838. https://doi.org/10.1080/02673037.2012.714465

Forbat, Liz, Roma Maguire, Lisa McCann, Nicola Illingworth and Nora Kearney, "The Use Of Technology in Cancer Care: Applying Foucault's Ideas to Explore the Changing Dynamic of Power in Health Care," Journal of Advanced Nursing 65:2 (2009), 306-315.

https://doi.org/10.1111/j.1365-2648.2008.04870.x

Foucault, Michel, "Technologies of the Self" [1982], in Technologies of the Self: A Seminar with

Michel Foucault, ed. Luther H. Martin, Huck Gutman and Patrick H. Hutton, 16-49. London: Tavistock Publishers, 1988.

Foucault, Michel. Discipline and Punish: The Birth of the Prison [1975]. London: Penguin, 1991.

Foucault, Michel, "The Subject and Power," Critical Inquiry 8:4 (1982), 777- 795. https://doi.org/10.1086/448181

Fox, Stephen, “The Panopticon: From Bentham's Obsession to the Revolution in Management Learning," Human Relations 42:8 (1989), 717-739.

https://doi.org/10.1177/001872678904200804

General Social Care Council, Regulating Social Workers (2001-12), Learning Report. GSCC: London, 2012.

Gilbert, Tony and Jason L. Powell. "Power and Social Work in the United Kingdom: A Foucauldian Excursion." Journal of Social Work 10:1 (2010), 3-22.

\section{https://doi.org/10.1177/1468017309347237}

Gourlay, Lesley, Transitions into the Academic World: Identities and Academic/Literary Practices. Oxford: Centre for Excellence in Preparing for Academic Practice, 2010.

Gourlay, Lesley. "New Lecturers and the Myth of 'Communities of Practice'," Studies in Continuing Education 33:1 (2011), 67-77.

\section{https://doi.org/10.1080/0158037X.2010.515570}

Griffiths, Vivienne, Simon Thompson and Liz Hryniewicz, "Developing a Research Profile: Mentoring and Support for Teacher Educators," Professional Development in Education 36:12 (2010), 245-262.

https://doi.org/10.1080/19415250903457166

Gutting, Gary, Foucault: A Very Short Introduction. Oxford: Oxford University Press, 2005. Kindle.

Hagyard, Andy, "Student Intelligence: Challenging Received Wisdom in Student Surveys," in The Future of Higher Education: Policy, Pedagogy and the Student Experience, ed. Les Bell, Howard Stevenson and Mike Neary, 112-125. London: Continuum, 2009.

Hakala, Johanna, "The Future of the Academic Calling? Junior Researchers in the Entrepreneurial University," Higher Education 57:2 (2009), 173-190.

https://doi.org/10.1007/s10734-008-9140-6 
Harding, Geoffrey and Kevin M. G. Taylor, "Academic Assessment in the Carceral Society," Pharmacy Education 1:2 (2001), 77-82.

https://doi.org/10.1080/15602210210333

Harrison, Jennifer and Frankie McKeown, "The Formal and Situated Learning of Beginning Teacher Educators in England: Identifying Characteristics for Successful Induction in the Transition from Workplace in Schools to Workplace in Higher Education," European Journal of Teacher Education 31:2 (2008), 151-168.

https://doi.org/10.1080/02619760802000131

Health and Care Professions Council, Registered Social Workers July 2014. London: HCPC 2014. Health and Care Professions Council, Guidance on Conduct and Ethics for Students. London: HCPC, 2016.

Hendrix, Katherine Grace, "Dialoguing with the "Communication Chorus": Mapping the Contours of the Morass," Southern Communication Journal 75:2 (2010), 127-136.

\section{https://doi.org/10.1080/10417941003613214}

Kelly, Adrian Peter, "Re-Stor(y)ing Power, Intimacy and Desire in Academic Work: Relational Academic Development and Learning Development in Practice," EdD. Diss., University of Technology, Sydney, 2012.

Laming, Lord, The Protection of Children in England: A Progress Report. London: The Stationery Office, 2009.

Lemke, Thomas, "Foucault, Governmentality, and Critique," Rethinking Marxism 14:3 (2002), 49-64. https://doi.org/10.1080/089356902101242288

Lincoln, Yvonna S. and Egon G. Guba, Naturalistic Inquiry. London: Sage, 1985.

Lucas, Lisa, The Research Game in Academic Life. Berkshire: Open University Press, 2006.

Macfarlane, Bruce, "Business and Management Studies in Higher Education: The Challenge of Academic Legitimacy," International Journal of Educational Management 9:5 (1995), 4-9.

https://doi.org/10.1108/09513549510095059

Manthorpe, Jill, "Settlement and Social Work Education: Absorption and Accommodation," Social Work Education, 21:4 (2002), 409 - 419.

https://doi.org/10.1080/02615470220150375

McAlpine, Lynn, Cheryl Amundsen and Marian Jazvac-Martek, "Living and Imagining Academic Identities." in Becoming an Academic: International Perspectives, ed. Lynn McAlpine and Gerlese Åkerlind, 125-154. Basingstoke: Palgrave Macmillan, 2010.

McLean, Katherine, "Reducing Risk, Producing Order: The Surprisingly Disciplinary World of Need Exchange," Contemporary Drug Problems 40:3 (2013), 415-445. https://doi.org/10.1177/009145091304000306

McMahon, Jennifer Ann and Dawn Penney, "(Self-) Surveillance and (Self-) Regulation: Living by Fat Numbers Within and Beyond a Sporting Culture," Qualitative Research in Sport, Exercise and Health 5:2 (2013), 157-178.

https://doi.org/10.1080/2159676X.2012.712998 
Mercer, Justine, "The Challenges of Insider Research in Educational Institutions: Wielding a Double-Edged Sword and Resolving Delicate Dilemmas," Oxford Review of Education 33:1 (2007), 1-17.

\section{https://doi.org/10.1080/03054980601094651}

Moffatt, Ken, "Surveillance and Government of the Welfare Recipient," in Reading Foucault for Social Work, ed. Adrienne S. Chambon, Allan Irving and Laura Epstein, 219-245. New York: Columbia University Press, 1999.

Moriarty, Jo, Jill Manthorpe, Martin Stevens, Shereen Hussein, Gillian MacIntyre, Joan Orme, Pam Green Lister, Endellion Sharpe, and Beth Crisp. "A Degree of Success? Messages from the New Social Work Degree in England for Nurse Education," Nurse Education Today 30:5 (2010), 443-447. https://doi.org/10.1016/j.nedt.2009.10.003

Morrison, Andrew, "Hegemony through Responsibilisation: Getting Working-Class Students into Higher Education in the United Kingdom," Power and Education 6:2 (2014), 118-129.

https://doi.org/10.2304/power.2014.6.2.118

Morrison, Marlene, "What Do We Mean by Educational Research?" in Research Methods in Educational Leadership and Management, ed. Ann R.J. Briggs and Marianne Coleman, 13-36. Second Edition. London: Sage, 2007.

Munro, Eileen, The Munro Review of Child Protection: Final Report - A Child Centred System: CM8062. London: Department for Education, 2011.

Murray, Jean, The Findings of the ESCalate Study on Teacher Educators' Induction into Higher Education. Bristol: ESCalate, 2006.

Noel, Penny, "The Secret Life of Teacher Educators: Becoming a Teacher Educator in the Learning and Skills Sector," Journal of Vocational Education and Training 58:2 (2006), 151170. https://doi.org/10.1080/13636820600799577

Nursing and Midwifery Council, Nurse Education: Now and In the Future. London: NMC, 2010. O'Farrell, Clare, Michel Foucault. London: Sage, 2005.

Office for Students. "TRAC Data." Accessed June 21, 2019. https://www.officeforstudents.org.uk/data-and-analysis/trac-data/

Olssen, Mark, "Neoliberal competition in higher education today: research, accountability and impact," British Journal of the Sociology of Education 37:1 (2016), 129-148.

https://doi.org/10.1080/01425692.2015.1100530

Orme, Joan, “Why Does Social Work Need Doctors?” Social Work Education 22:6 (2003), 541554.

\section{https://doi.org/10.1080/0261547032000142652}

Peckover, Sue, "Supporting and Policing Mothers: An Analysis of the Disciplinary Practices of Health Visiting," Journal of Advanced Nursing 38:4 (2012), 369-377.

https://doi.org/10.1046/j.1365-2648.2002.02197.x

Pettifer, Anne and Lynn Clouder, "Clinical Supervision: A Means of Promoting Reciprocity Between Practitioners and Academics," Learning in Health and Social Care 7:3 (2008), 168177.

https://doi.org/10.1111/j.1473-6861.2008.00186.x 
Powell, Jackie and Joan Orme, "Increasing the Confidence and Competence of Social Work

Researchers: What Works?," British Journal of Social Work 41:8 (2011), 1566-1585.

https://doi.org/10.1093/bjsw/bcr027

Rubin, Allen, "Standards for Rigor in Qualitative Inquiry," Research on Social Work Practice 10:2 (2000), 173-178.

https://doi.org/10.1177/104973150001000201

Saldaña, Johnny, The Coding Manual for Qualitative Researchers. London: Sage, 2013.

Shreeve, Alison, "Being in Two Camps: Conflicting Experiences for Practice-Based Academics," Studies in Continuing Education 33:1 (2011), 79-81.

https://doi.org/10.1080/0158037X.2011.521681

Sidhu, Ravinder Kaur, Universities and Globalization: To market, to Market. London: Lawrence Erlbaum Associates, 2006.

Simpson, Diane, "Being and Becoming a Social Work Academic: Negotiating Transitions and Identities," EdD diss., University of Lincoln, 2016.

Sobiechowska, Paula, "The Professional-Academic: Negotiating the Relationships Between Professional, Practitioner and Academic Identities Among Social Worker and Nurse Educators," Phd diss., UCL Institute of Education, 2016.

Social Work Reform Board, Building a Safe and Confident Future: Maintaining Momentum.

London: Department for 2012.

https://assets.publishing.service.gov.uk/government/uploads/system/uploads/attachmen t data/file/175947/SWRB progress report - June 2012.pdf

TRAC. “TRAC Case Study: Academic Time Allocation, Statistical Method." accessed June 21, 2019. https://www.trac.ac.uk/wp-content/uploads/2018/07/TRAC-case-study-Academictime-allocation.pdf

Warren, Simon, "Struggling for visibility in higher education: caught between neoliberalism 'out there' and 'in here' - an autoethnographic account," Journal of Education Policy 32:2 (2017), 127-140. https://doi.org/10.1080/02680939.2016.1252062

Wilson, Fiona and Sandra Nutley, "A Critical Look at Staff Appraisal: The Case of Women in Scottish Universities," Gender, Work and Organization 10:3 (2003), 301-319. https://doi.org/10.1111/1468-0432.00197

Author info

Dr Diane Simpson diane.simpson@sunderland.ac.uk Senior Lecturer in Social Work Faculty of Education and Society School of Social Sciences University of Sunderland UK 
Dr Sarah Amsler

sarah.amsler@nottingham.ac.uk

Tel: +441159514 412

Associate Professor in Education

School of Education

University of Nottingham

UK

Diane Simpson is a Senior Lecturer in Social Work at the University of Sunderland, UK. Diane has been involved in social work higher education since 2006 and previously worked for Teesside University and the University of Lincoln. Diane continues to be a registered social worker with Social Work England. Diane's research interests are varied. Her doctorate examined the experiences of social workers who become social work academics, examined through a Foucauldian theoretical framework. Diane is also interested in co-production of research with students and has recently been the academic lead for a student as researcher project at Teesside University evaluating an undergraduate student buddying scheme. Increasingly, Diane has become involved in public health related research projects.

Sarah Amsler is an Associate Professor of Education at the University of Nottingham, UK. Her work focuses on learning at the limits of the possible and with the 'otherwise', ontological politics in projects for systemic social change, pedagogies of possibility and hope, and problems of coloniality in educational practice. She has an interest in critical approaches to higher education policy studies. 